BMJ Paediatrics Open

\section{Helicobacter pylori infection in children}

To cite: Aguilera Matos I, Diaz Oliva SE, Escobedo AA, et al. Helicobacter pylori infection in children. BMJ Paediatrics Open 2020;4:e000679. doi:10.1136/ bmjpo-2020-000679

Received 6 May 2020

Revised 26 June 2020

Accepted 29 June 2020
Check for updates

(C) Author(s) (or their employer(s)) 2020. Re-use permitted under CC BY-NC. No commercial re-use. See rights and permissions. Published by BMJ.

${ }^{1}$ Pediatric Gastroenterology, Institute of Gastroenterology, Havana, Cuba

${ }^{2}$ Epidemiology, Institute of Gastroenterology, Havana City, Havana, Cuba

${ }^{3}$ Research department, Institute of Gastroenterology, Havana, Cuba

Correspondence to MD Idalmis Aguilera Matos; idaguilera@infomed.sld.cu

\section{ABSTRACT}

Helicobacter pylori infection affects more than half of the world population and it occurs generally in childhood. It is associated with gastroduodenal ulcer, gastric atrophy, intestinal metaplasia, gastric adenocarcinoma and lymphoid tissue-associated lymphoma. It is difficult to eradicate this bacterium due to its high antimicrobial resistance. In children, the infection is asymptomatic in the majority of cases and complications are less common. Probable inverse relationships with allergic diseases and inflammatory bowel diseases are being studied. These reasons mean that the decision to diagnose and treat the infection in children is only considered in specific circumstances in which it provides true benefits. This review focuses on some current considerations regarding epidemiology, diagnosis and treatment of childhood infection, emphasising outcomes and treatment schemes in children.

\section{INTRODUCTION}

Helicobacter pylori is a Gram-negative microaerophilic bacteria. It has been found in mummies, but was first described when it was related to chronic gastritis and peptic ulcer disease in 1983 by Barry Marshall and Robin Warren. ${ }^{1}$ This discovery was the beginning of numerous investigations to amplify knowledge of this bacterium.

The prevalence of infection in paediatric age is high and varies from country to country and in the same geographical area. It colonises the gastric mucosa generally in childhood, and passes asymptomatically in most patients, in which it will remain in the gastric cavity throughout life in the absence of eradication therapy. ${ }^{2}$ Infected patients may develop chronic active gastritis, peptic ulcer disease $10 \%$, gastric cancer $1 \%-3 \%$ and will present with mucosa-associated lymphoid tissue lymphoma $0.1 \%$. All these complications occur in their vast majority in adulthood. ${ }^{34}$ The development of the disease is related to the virulence of the strain, the genetic predisposition, the host's immune response, the time of exposure and environmental factors. The CagA+ and VacA s1m1 strains are considered the most pathogenic and carry a higher risk of precancerous lesions. The risk seems higher if infection with these strains occurs simultaneously and in childhood. ${ }^{56}$
The prevalence of infection in adults tends to decrease in some parts of the world. The increasing resistance to antibiotics, as well as the lack of therapeutic alternatives that achieve $90 \%$ eradication effectively make infection a complex scenario.

The diagnosis and treatment should not be considered in the same way in children and adults. The immune mechanisms against infection differ at both stages of life and therefore the decision to investigate and treat infection in childhood is indicated in a small proportion of patients in whom the benefits are greater considering that recurrence and complications largely occur from ineffective treatments.

\section{EPIDEMIOLOGY}

H. pylori has infected approximately $50 \%$ of the total population. ${ }^{7}$ The prevalence is known in children worldwide and varies among countries. It is lower in high-income countries $(34.7 \%)$ than in low-income and middle-income countries $(50.8 \%)$, more prevalent in adults than in children and may also vary in a geographic area within a country. ${ }^{7}$ The highest rates have been cited in Nigeria, Serbia, South Africa, Nicaragua and Colombia with $89.7 \%, 88.3 \%, 86.8 \%$, $83.3 \%$ and $83.1 \%$, respectively, and the lowest in Yemen, Indonesia, Belgium, Ghana and Sweden with $8.9 \%, 10.0 \%, 11 \%, 14.2 \%$ and $15 \%,{ }^{8}$ respectively. In Latin America, 52\% of children and adolescents are infected. ${ }^{9}$ Improvement in sanitary conditions, as well as decreased transmission have been the reasons why the prevalence has decreased in many parts of the world.

\section{TRANSMISSION}

Several studies describe that person-toperson transmission among family members is frequent, with mother-to-child being the most predominant and the most important transmission route being oral-oral and oralfaecal. ${ }^{10}$ Contaminated water can also be a source of infection, in which the bacterium 
Table 1 Clinical presentation

\section{Clinical manifestations}

Asymptomatic

Digestive manifestations

Nausea

Epigastric pain Meta-analysis showed significant association between nausea and and
Helicobacter pylori infection. ${ }^{12}$ The infection should not be investigated.

Meta-analysis documented statistical significant association. ${ }^{13}$ Other studies do not find predominance of this symptom in infected cases. It is a common indication of OEGD.

Chronic abdominal pain without any alarm signs The pain is probably independent of the presence of $H$. pylori. The infection or symptoms

Vomiting

Heartburn, halitosis, regurgitation should not be investigated or treated.

Meta-analysis showed no direct link between infection and vomiting. ${ }^{13}$

Non-specific symptom. It does not constitute indication of study or treatment.

Extradigestive manifestations

Unexplained iron deficiency anaemia

After other causes have been ruled out, the infection should be investigated.

Chronic immune thrombocytopenic purpura

Unexplained thrombocytopenia should undergo $H$. pylori testing. Eradication and therapy have shown promising results with improved platelet counts and the normalisation of autoplatelet antibodies without relapse.

\section{Henoch-Schonlein purpura}

Inflammatory bowel disease

Bronchial asthma, other allergic diseases

EGD, oesophago-gastro-duodenoscopy.

can remain for long periods in a viable state. Many associate $H$. pylori infection with socioeconomic conditions and dietary habits, suggesting that foods such as milk, meat and vegetables may be an important route of transmission. Saliva is also another possible source of infection. ${ }^{11}$

\section{CLINICAL MANIFESTATIONS}

The infection is acquired around 10 years of age and approximately $85 \%$ have long asymptomatic periods. ${ }^{24}$ Clinical manifestations (table 1 ) are non-specific and some may be justified by the presence of complications. A statistically significant positive association with nausea, but no significant association between gastrointestinal symptoms, pain or pain characteristics and infection has been documented. ${ }^{12}$ Other studies have found that symptoms decrease in frequency and intensity or disappear with or without eradicating the bacteria. A meta-analysis attempted to establish a possible association between infection and symptoms, and concluded that it was not related to vomiting, diarrhoea, flatulence, chronic functional abdominal pain, halitosis, regurgitation, constipation or nausea. However, they documented a statistically significant association with epigastric pain. ${ }^{13}$ Persistent vomiting, digestive bleeding, iron deficiency anaemia (IDA) of unspecified cause, malnutrition may be due to complications from the infection or another diagnosis and therefore require investigation.
H. pylori may a play role in some extraintestinal disease like unexplained IDA, immune thrombocytopenic purpura (ITP), Henoch-Schonlein purpura, bronchial asthma, other allergic diseases and inflammatory bowel disease (IBD). There are conflicting study results regarding the protection or inverse relationship of $H$. pylori and bronchial asthma, other allergic diseases and IBD. ${ }^{14}{ }^{15}$ A meta-analysis suggests that $H$. pylori may have immunoregulatory properties in IBD, and the inverse association seems stronger in paediatric patients and those with Crohn's disease. ${ }^{16}{ }^{17}$ Another meta-analysis supports the inverse relationship of infection with the risk of bronchial asthma, especially in CagA+ patient. ${ }^{18}$ Future research is required in this regard.

\section{DIAGNOSTIC METHODS}

There are multiple invasive and non-invasive methods for the diagnosis of $H$. pylori infection, with different levels of sensitivity and specificity (table 2 ) ${ }^{19}{ }^{20}$ The initial diagnosis in children should be performed through invasive methods and the evaluation of the response through non-invasive methods. ${ }^{2}$

The initial point of investigation in children begins with upper endoscopy or oesophago-gastro-duodenoscopy (OEGD) for different indications. Although this procedure does not allow direct diagnosis, with high-definition endoscopic techniques like Blue Light Imaging and Linked Colour Imaging are helpful in characterisation of mucosal 
Table 2 Diagnostic methods for Helicobacter pylori infection

\begin{tabular}{|c|c|c|}
\hline Methods & Advantages & Disadvantages \\
\hline \multicolumn{3}{|l|}{ Invasive } \\
\hline Histology & $\begin{array}{l}\text { Degree of chronic inflammation and } \\
\text { activity, diagnosis of premalignant lesions } \\
\text { such as grade of atrophy and gastric } \\
\text { intestinal metaplasia, malignancy and }\end{array}$ & $\begin{array}{l}\text { Need special skills, and costly observer-dependency; } \\
\text { time-consuming; dependence of accuracy on the receiver } \\
\text { of antibiotics, proton pump inhibitors (PPI); size,site and } \\
\text { number of biopsies. }\end{array}$ \\
\hline
\end{tabular}

$\begin{array}{ll}\text { Culture } & \text { Specificity (100\%), provides pattern of } \\ \text { antimicrobial resistance. }\end{array}$

Rapid urease test
Rapid, inexpensive, high sensitivity and specificity (almost 100\%).

Important location of the biopsies, digestive haemorrhage, recent treatments with antibiotics, PPI, bismuth; is expensive and time-consuming test. Sensitivity on the staff skill and culture media.

False-negative: bismuth, antibiotics, PPI, achlorhydria and the prevalence rate of infection, bacteria density digestive haemorrhage.

False-positive: Proteus mirabilis, Citrobacter freundii, Klebsiella pneumoniae, Enterobacter cloacae, Staphylococcus aureus.

\begin{tabular}{lll}
$\begin{array}{l}\text { Non-invasive or invasive } \\
\text { PCR }\end{array}$ & $\begin{array}{l}\text { Antimicrobial susceptibility, fast, high } \\
\text { sensitivity and specificity. }\end{array}$ & $\begin{array}{l}\text { False-positive results due to detect DNA pieces of dead } \\
\text { bacteria. }\end{array}$ \\
$\begin{array}{l}\text { Non-invasive } \\
\text { Urea breath test }\end{array}$ & $\begin{array}{l}\text { Ideal for evaluating treatment response in } \\
\text { children over } 6 \text { years of age. }\end{array}$ & $\begin{array}{l}\text { High false-positive results in children aged }<6 \text { years; false- } \\
\text { negative in recent treatments with bismuth, PPI antibiotics, } \\
\text { not to use in children as an initial diagnosis. }\end{array}$ \\
\hline Stool antigen test & $\begin{array}{l}\text { No age dependency; fast, easy; useful } \\
\text { after therapy. }\end{array}$ & $\begin{array}{l}\text { False-negative results in recent treatments with bismuth, } \\
\text { PPI, antibiotics; dependency of accuracy on the cut-off } \\
\text { value and treatment status. }\end{array}$ \\
\hline Serology & Widely available, cheapest. & $\begin{array}{l}\text { Sensitivity in children is low, not used to confirm the } \\
\text { eradication, inability to detect acute or chronic infection. }\end{array}$
\end{tabular}

PPI, proton pump inhibitor.

changes in chronic gastritis, allowing the selection of areas for sample collection. ${ }^{21}$ The most frequent endoscopic diagnosis in children is nodular gastritis. Initially $H$. pylori colonises the antrum and can produce antral gastritis and if the infection persists nodular, pangastritis. ${ }^{10}$ This can also be observed in Crohn's disease, cooeliac disease, allergic diseases, eosinophilic gastritis, collagen, autoimmune, lymphoma, cytomegalovirus infection and other infectious causes and therefore these causes must be ruled out. In this context, the infection can be diagnosed and the first challenge begins, in deciding whether to treat or not. OEGD should be indicated to investigate the cause of symptoms, not the presence of $H$. pylori infection. ${ }^{2}$

Unlike adults, gastroduodenal ulcers in children are infrequent. Samples should be taken for biopsy and the infection confirmed. Other causes, however, need to be considered. Gastric atrophy and intestinal metaplasia are less frequent as compared with adults, ${ }^{22}$ and are more related to time exposure.

During the procedure and for the initial diagnosis, at least six samples must be taken. Two samples, of the antrum and the body taken for histopathological study, for which the Sydney classification should be used. Two samples for culture, one from the antrum and the other from the corpus and lastly a sample for rapid urea test (RUT) or other molecular method: PCR or fluorescence in situ hybridisation (FISH) ${ }^{2}$

The sensitivity of all invasive methods is compromised by the use of antibiotics, bismuth, proton pump inhibitors (PPI) and upper gastrointestinal bleeding.

Culture has a specificity of $100 \%$ but the sensitivity is compromised by the use of antibiotics, H2-receptor antagonists, PPI, bismuth, alcohol drinking, digestive bleeding, high activity of gastritis, low bacterial load the quality of the sample collection, the patchy distribution of $H$. pylori, transport of biopsies, staff skills and culture media. For these reasons, it should not be used as the only diagnostic method. A negative culture does not exclude infection. This has the advantage of providing antimicrobial sensitivity data to offer strain-directed treatment. Ideal is to provide this method for initial diagnosis but when it is available generally is reserved for cases with a first time failure. ${ }^{2} 1920$

However, it is known that in vitro sensitivity does not always respond to successful eradication in vivo, patients may be colonised by several strains, also strains isolated in various sites may have different susceptibilities to 
antimicrobials, additionally a patient may have multiresistant strains.

PCR provides excellent specificity and sensitivity. It also allows detection of specific mutations leading to antibiotic resistance, such as fluoroquinolone and macrolides. It is more reliable to detect hetero-resistant status. PCR can also be performed from stool samples, saliva and gastric juice. Studies reported a more frequent CagA+ VacAs1m1 in children and adolescents. ${ }^{4} 1920$

RUT is a very cheap and fast method, with a good sensitivity and specificity, although the sensitivity is affected in young children, with the use of antibiotics, PPI, bismuth and digestive bleeding.

Histology allows for the presence of bacteria to be identified. Provides details of the activity, degree of chronic inflammation, presence of lymphoid follicles, diagnosis of coccoid forms and also premalignant lesions such as atrophic gastritis and intestinal metaplasia that lead to close monitoring of the patient. To improve the sensitivity, it is important to take several samples. Neutrophil infiltration is less significant in children than adults but infiltration by lymphocytes, plasma cells and immunosuppressive $\mathrm{T}$ regulatory cells are more significant. ${ }^{2} 1920$

Non-invasive methods are not indicated to make an initial diagnosis of infection in children. The stool antigen test (SAT) and ${ }^{13} \mathrm{C}$-urea breath test (UBT) are used to evaluate eradication and are indicated 4 weeks after the end of treatment. These tests are only used as initial research when investigating causes of ITP, only if EGD cannot be performed. ${ }^{2}$ If the SAT is positive after treatment, it is prudent to perform UBT in children. Some studies recommend that, after the eradication confirmed by these methods, an annual non-invasive technique should be performed, especially in areas of high prevalence or in at-risk individuals, for the recrudescence diagnosis. $^{211}$

Antibody-based tests for H. pylori in serum, whole blood, urine and saliva are not modified by treatment with PPI or antimicrobials but their utility is more accurate for epidemiological purposes. The antibodies remain for a time after eradication and it does not allow differentiate between current and past infection.

\section{DIAGNOSIS}

In children the diagnosis is confirmed through invasive methods and is limited to patients in whom benefits are expected: in gastroduodenal ulcer and/or erosive gastritis, refractory IDA in which other causes have been ruled out and when investigating causes ITP. ${ }^{2}$ The diagnosis is confirmed by the following (figure 1):

1. Positive culture.

2. If culture is not available or is negative: two invasive methods (histology and RUT or some molecular method: PCR or FISH).

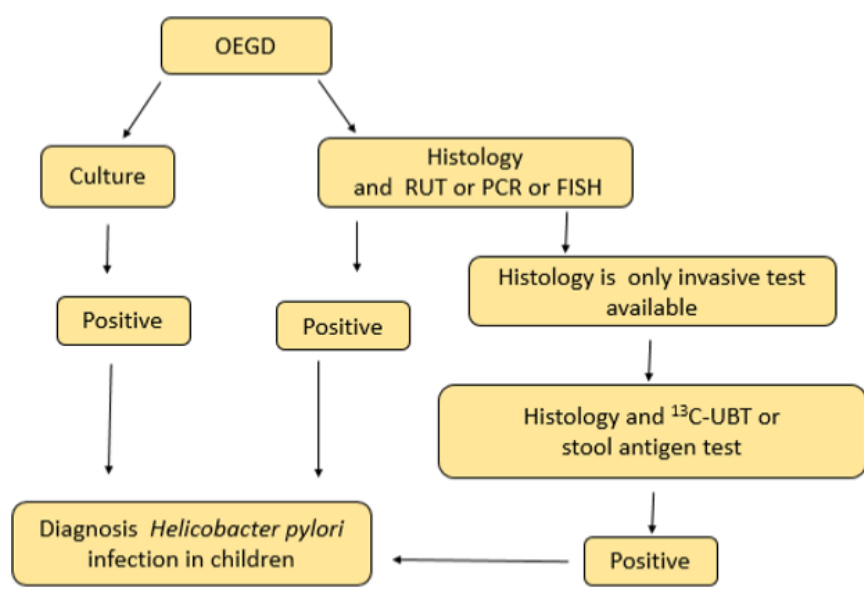

Figure 1 Legends ${ }^{13} \mathrm{C}-U B T$ : urea breath test; OEGD: oesophago-gastro-duodenoscopy; FISH: fluorescence in situ hybridisation; RUT: rapid urea test.

3. If culture is not available or it is negative and only histology is available, a non-invasive method can be used (UBT or SAT).

\section{TREATMENT}

Without a treatment scheme, eradication is highly improbable. Spontaneous eradication is described mainly in infants and young children; the eradication decreases with age. ${ }^{23}$ Research and treatment in children is controversial due to the prevalence of infection in a geographical area, the incidence of age-related cancer, high rates of antimicrobial resistance along with the presence of complications associated with $H$. pylori. It would be beneficial to treat at an age that reinfections are less probable ( $>12$ years) before reaching non-return premalignant lesions, such as atrophic gastritis and intestinal metaplasia. ${ }^{24}$ The most virulent strains increase the risk of cancer three times, all can cause chronic inflammation and diseases; hence, it is not necessary to know the strain to decide to treat. ${ }^{25}$

Treatment is indicated in children with gastroduodenal ulcer and refractory IDA in which other causes have been ruled out. Eradication of $H$. pylori infection need to be also considered in patients with ITP. ${ }^{26}$ In contrast, for asymptomatic children, chronic functional abdominal pain, short stature, first-degree family with gastric cancer and family with $H$. pylori infection, treatment is not indicated. ${ }^{2}$ In those patients in which the diagnosis is incidental histopathological finding during OEGD performed for other possible diseases, IBD, eosinophilia disease, among others, only should be treated after an analysis with the parents or legal relatives in which they should be oriented in favour of treatment (risk of complications at later ages) and against (infrequency of complications at this age, reinfections, adverse reactions, change in the intestinal microbiota, possible protective effects against other diseases, reduces the alternatives for subsequent treatments if necessary and the need for treatment adherence to achieve successful eradication). ${ }^{2}$ 
Table 3 First-line therapy

\section{Known susceptibility}

\begin{tabular}{|c|c|c|c|}
\hline CLA and MET susceptible & $\begin{array}{l}\text { CLA susceptible } \\
\text { MET resistant }\end{array}$ & $\begin{array}{l}\text { MET susceptible } \\
\text { CLA resistant }\end{array}$ & $\begin{array}{l}\text { Unknown susceptibility or } \\
\text { double resistance }\end{array}$ \\
\hline $\begin{array}{l}\text { Triple therapy } 14 \text { days } \\
\text { Omeprazole/esomeprazol } 20- \\
40 \text { mg twice daily } \\
\text { Amoxicillin } 500-1000 \text { mg twice } \\
\text { daily } \\
\text { CLA } 250-500 \text { mg twice daily }\end{array}$ & $\begin{array}{l}\text { Triple therapy } 14 \text { days } \\
\text { Omeprazole/esomeprazol } \\
20-40 \text { mg twice daily } \\
\text { Amoxicillin } 500-1000 \mathrm{mg} \\
\text { twice daily } \\
\text { CLA } 250-500 \mathrm{mg} \text { twice daily }\end{array}$ & $\begin{array}{l}\text { Triple therapy } 14 \text { days } \\
\text { Omeprazole/esomeprazol } \\
20-40 \mathrm{mg} \text { twice daily } \\
\text { Amoxicillin } 500-1000 \mathrm{mg} \\
\text { twice daily } \\
\text { Metronidazole } 250-500 \mathrm{mg} \\
\text { twice daily }\end{array}$ & $\begin{array}{l}\text { Triple therapy } 14 \text { days with } \\
\text { high-dose amoxicillin } \\
\text { Omeprazole/esomeprazol } \\
20-40 \text { mg twice daily } \\
\text { Amoxicillin } 750-1500 \mathrm{mg} \text { twice } \\
\text { daily } \\
\text { Metronidazole } 250-500 \mathrm{mg} \\
\text { twice daily }\end{array}$ \\
\hline
\end{tabular}

Alternative treatment options

Sequential therapy ${ }^{\star} 10$ days
Bismuth-based $† 14$ days

\section{Bismuth-based $\dagger 14$ days}

Bismuth-based $\dagger 14$ days

Concomitant therapy $\neq 14$ days

Data from ESPGHAN/NASPGHAN guidelines. ${ }^{2}$

*Sequential therapy: PPI-amoxicillin 5 days and PPI-CLA-MET 5 days.

†Bismuth-based: children aged $>8$ years: bismuth-PPI-MET-tetracycline and children aged $<8$ years: bismuth-PPI-amoxicillin-MET 10-14 days. Bismuth dose: children aged $>10$ years: 524 four times a day, children aged $<10$ years: 262 four times a day.

$\ddagger$ Concomitant therapy: PPI-amoxicillin-CLA-MET 14 days.

CLA, clarithromycin; MET, metronidazole; PPI, proton pump inhibitor (dose should be adapted if use rabeprazole).

Treatment regimens for first-line therapy should provide a cure rate of at least $90 \%$. Excessive indication of antibiotics or ineffective treatment regimens for $H$. pylori infection has led to an increase in the resistance of key antibiotics for treatment.

Adapting the first line of treatment according to susceptibility would be ideal (table 3 ), but we know that in practice it is difficult so therefore in many regions treatment is indicated empirically. Clarithromycin (CLA) is the choice of treatment in patients with susceptible strains. If the resistance rate exceeds $15 \%-20 \%$ in that region, it should not be used unless sensitivity to this antibiotic is known in the patient ${ }^{2}{ }^{4}$; therefore, in patients with known sensitivity to CLA and metronidazole (MET), the first recommended option is PPI-AMO-CLA. They can use sequential therapy as alternative treatment. In those with known resistance to CLA, triple therapy with PPIAMO-MET is indicated, and PPI-AMO-CLA for those with resistance to MET. In both cases, bismuth therapy can be used as an alternative treatment. Patients with unknown susceptibility or double resistance are not recommended to treat with PPI-AMO-CLA. Triple therapy with high doses of AMO can be considered as the first line of treatment, as well as bismuth-based and concomitant therapy as treatment alternatives. Treatment regimens and doses are based on European Society for Paediatric Gastroenterology, Hepatology and Nutrition (ESPGHAN) and North American Society for Paediatric Gastroenterology, Hepatology and Nutrition (NASPGHAN) guidelines. ${ }^{2}$

There is high resistance to CLA and MET, mainly CLA in children and MET in adults. It varies with region and is an increasing trend. ${ }^{4}$ In the studies reviewed in children within the last 5 years, we observed that in most of them the resistance rates to CLA and MET exceed 20\%, with CLA resistance prevailing and with very little resistance to amoxicillin (AMO) and levofloxacin. ${ }^{27-29}$ Multidrug resistance was a problem. ${ }^{27} 28{ }^{30}$ Resistance increases considerably in treatment failures. ${ }^{28} 31$ The hetero-resistance in strains was described in children. ${ }^{27}$ Studies demonstrated that triple therapy with PPI-AMO-CLA offers acceptable eradication rates when the strains are sensitive, and the resistance to MET does not significantly influence eradication. ${ }^{32-34}$ Authors reported patients with susceptibilityguided treatment with adherence $>90 \%$ of treatment achieved acceptable rates of eradication, ${ }^{30} 35$ the rates were significantly higher in those receiving sequential therapy. ${ }^{35}$ High doses of MET with triple therapy for 10 days in patients without culture improved eradication rates, although the desired ones were not achieved. ${ }^{34}$ One study (although with limitations) compared four schemes in patients who had not received previous treatments. Therapies with bismuth, concurrent, sequential and triple therapy were offered for 14 days; eradication rates of $89.8 \%, 84.6 \%, 74.1 \%$ and $69.5 \%$ were achieved. There was no significant difference between the adverse effects in the regimens used, despite prolonging the duration of sequential therapy; it was not possible to improve the eradication rate. ${ }^{36}$

PPI plays a key role in treatment; double doses are recommended to improve susceptibility to AMO and CLA and to overcome rapid degradation with individual differences of CYP450 cytochrome polymorphisms. Vonoprazan is a potent antisecretory that is used in children, achieving rates higher than those obtained with PPI-AMO-CLA for a period of 7 days eradication. ${ }^{37}$ The bismuth is a drug that has been shown to have effect against $H$. pylori. Studies in adults have shown that it improves the efficacy of the antimicrobials used and has offered better results in patients with resistance to CLA. ${ }^{38}$ MET resistance can be partially overcome if doses are 
CLA and MET susceptible

\begin{tabular}{|c|c|c|c|c|c|c|}
\hline $\begin{array}{l}\text { Previous } \\
\text { treatment }\end{array}$ & $\begin{array}{l}\text { Triple therapy } \\
\text { OAC }^{\star}\end{array}$ & $\begin{array}{l}\text { Triple therapy } \\
\text { OAM† }\end{array}$ & $\begin{array}{l}\text { Sequential } \\
\text { therapy }\end{array}$ & $\begin{array}{l}\text { Triple therapy } \\
\mathrm{OAC}^{\star}\end{array}$ & $\begin{array}{l}\text { Triple therapy } \\
\text { OAM } \dagger\end{array}$ & $\begin{array}{l}\text { Primary antimicrobial } \\
\text { unknown susceptibility }\end{array}$ \\
\hline $\begin{array}{l}\text { Rescue } \\
\text { therapy }\end{array}$ & $\begin{array}{l}\text { Triple therapy } \\
\text { OAM } † \\
14 \text { days }\end{array}$ & $\begin{array}{l}\text { Triple therapy } \\
\text { OAC }^{*} \\
14 \text { days }\end{array}$ & $\begin{array}{l}\text { Consider } \\
\text { endoscopy use } \\
\text { treatment } 14 \\
\text { days or treat } \\
\text { like double } \\
\text { resistence } \neq\end{array}$ & $\begin{array}{l}\text { Consider } \\
\text { endoscopy use } \\
\text { treatment } 14 \text { days } \\
\text { or treat like double } \\
\text { resistence }\end{array}$ & $\begin{array}{l}\text { Treat like } \\
\text { double } \\
\text { resistence }\end{array}$ & $\begin{array}{l}\text { Consider endoscopy } \\
\text { to antimicrobial } \\
\text { susceptibility or treat } \\
\text { like double resistenceł }\end{array}$ \\
\hline
\end{tabular}

Data from ESPGHAN/NASPGHAN guidelines. ${ }^{2}$

Sequential therapy, bismuth-based and concomitant therapy: see table 3.

${ }^{*} \mathrm{OAC}$ : PPI-amoxicillin-clarithromycin.

†OAM: PPI-amoxicillin-metronidazole.

$\ddagger$ Double resistance: triple therapy with high-dose amoxicillin 14 days, bismuth-based, concomitant therapy 14 days.

CLA, clarithromycin; MET, metronidazole; PPI, proton pump inhibitor.

increased and treatment days are prolonged. Levofloxacin or tetracycline may be used in children older than 8 years. $^{2}$

After a failure in the first therapy, it would be necessary to determine antimicrobial resistance before the next treatment. ${ }^{2}$ Treatment schemes in rescue therapies can be seen in table 4 .

A meta-analysis on the use of probiotics in $H$. pylori infection suggested that supplementation with Lactobacillus to treatment improves adverse effects such as diarrhoea when used at higher and longer doses. It may benefit eradication. ${ }^{39}$

Recurrence of infection can occur by recrudescence or reinfection. Recrudescence is when a strain that caused the recurrence is genetically identical to that isolated before receiving the eradication treatment, and reinfection is when the strain is genetically different. Recurrence rates are reported during the 3-12 months after eradication, decreases over time, declining sharply after 1 year. ${ }^{23}$ Annual reinfection rates are lower than those of recrudescence and are extremely low in high-income countries. Reinfection in children over the age of 5 and adults is considerably low. After eradication, the maintenance of documented negativity for 1 year or more may be an indicator against recrudescence. Therefore, an ineffective therapy appears to produce a recrudescence of infection. ${ }^{11} 40$

Studies between different treatment regimens in children are mostly based on comparing sequential therapy and triple therapy in 10-14 days with standard PPI doses. In those treatments in which the susceptibility is unknown, acceptable rates were nor achieved. Sequential therapy shows no benefits by extending it to 14 days. For treatment selection, it is necessary to know the local rates of antimicrobial resistance and if they are not available, at least to know which is locally reliable, it is necessary to know the drug history with macrolides, nitroimidazoles and quinolones.

Treatment should be individualised according to susceptibility for 14 days (except sequential therapy) with high doses. The use of probiotics can be beneficial since it improves the adverse effects of the medication and therefore the adherence to the treatment that is necessary for a successful eradication. Further studies related to adherence of different treatment regimens, higher doses of PPI and quadruple therapies, especially in patients with unknown susceptibility, multiresistant strains and treatment failure are needed. In adults, many studies suggest quadruple therapies as the first line of treatment.

\section{CONCLUSIONS}

The decision to investigate and treat $H$. pylori infection in children should be based on providing true benefits, taking into account the low frequency of complications at this stage, the recurrence of infection, the probable inverse relationships with allergic and immunological diseases, antimicrobial resistance as well as the few treatment alternatives available for treating the infection in children.

Acknowledgements The authors thanks Dr. Adrian Van-Nooten for his linguistic advice

Contributors The following document includes the participation of each author in the manuscript. Everything was recorded on the basis of the joint decision. IA-M: planned the study, searched and selecting articles in the PubMed and Cochrane Library search engines, performed analysis and interpretation of data, writing of the manuscript, approval of final version and responsible for overall content. SED-0: searched and selecting articles in the PubMed and Cochrane Library search engines, performed analysis and interpretation of data, writing of the manuscript and approval of final version. AAE: searched and selecting articles in the PubMed and Cochrane Library search engines, approval of final version and manuscript review. OMVJ: searched and selecting articles in the PubMed and Cochrane Library search engines, writing of the manuscript and approval of final version. YdCVV: writing of the manuscript and approval of final version.

Funding The authors have not declared a specific grant for this research from any funding agency in the public, commercial or not-for-profit sectors.

Competing interests None declared.

Patient consent for publication Not required.

Provenance and peer review Commissioned; externally peer reviewed.

Data availability statement Data sharing not applicable as no datasets generated and/or analysed for this study. There are no data in this work. 
Open access This is an open access article distributed in accordance with the Creative Commons Attribution Non Commercial (CC BY-NC 4.0) license, which permits others to distribute, remix, adapt, build upon this work non-commercially, and license their derivative works on different terms, provided the original work is properly cited, appropriate credit is given, any changes made indicated, and the use is non-commercial. See: http://creativecommons.org/licenses/by-nc/4.0/.

ORCID iDs

Idalmis Aguilera Matos http://orcid.org/0000-0002-7364-1533

Sarah Esther Diaz Oliva http://orcid.org/0000-0002-6611-4823

Angel A Escobedo http://orcid.org/0000-0002-6241-3340

Oscar Manuel Villa Jiménez http://orcid.org/0000-0002-6675-584X

\section{REFERENCES}

1 Warren JR, Marshall B. Unidentified curved bacilli on gastric epithelium in active chronic gastritis. Lancet 1983;1:1273-5.

2 Jones NL, Koletzko S, Goodman K, et al. Joint ESPGHAN/ NASPGHAN guidelines for the management of Helicobacter pylori in children and adolescents (update 2016). J Pediatr Gastroenterol Nutr 2017;64:991-1003.

3 Malfertheiner P, Megraud F, O'Morain CA, et al. Management of Helicobacter pylori infection-the Maastricht V/Florence consensus report. Gut 2017;66:6-30.

4 Cilleruelo PM, González MM. Infección POR Helicobacter pylori en El niño, ¿está sobrediagnósticada? Act Pediatr Aten Prim 2018;11:60-2.

5 Iwanczak B, Laszewicz W, Iwanczak F, et al. Genotypic and clinical differences of seropositive Helicobacter pylori children and adults in the Polish population. J Physiol Pharmacol 2014;65:801-7.

6 González CA, Figueiredo C, Lic CB, et al. Helicobacter pylori cagA and vacA genotypes as predictors of progression of gastric preneoplastic lesions: a long-term follow-up in a high-risk area in Spain. Am J Gastroenterol 2011;106:867-74.

7 Hassan M, Arif A, Ms S, et al. Global prevalence of Helicobacter pylori and its effect on human health-Pakistan. Pure and Applied Biology 2020:936-48.

8 Zamani M, Ebrahimtabar F, Zamani V, et al. Systematic review with meta-analysis: the worldwide prevalence of Helicobacter pylori infection. Aliment Pharmacol Ther 2018;47:868-76.

9 Curado MP, de Oliveira MM, de Araújo Fagundes M. Prevalence of Helicobacter pylori infection in Latin America and the Caribbean populations: a systematic review and meta-analysis. Cancer Epidemiol 2019;60:141-8.

10 Okuda M, Lin Y, Kikuchi S. Helicobacter pylori infection in children and adolescents. Adv Exp Med Biol 2019;1149:107-20.

11 Kayali S, Manfredi M, Gaiani F, et al. Helicobacter pylori, transmission routes and recurrence of infection: state of the art. Acta Biomed 2018;89:72-6.

12 Correa Silva RGS, Machado NC, Carvalho MA, et al. Helicobacter pylori infection is high in paediatric nonulcer dyspepsia but not associated with specific gastrointestinal symptoms. Acta Paediatr 2016;105:e228-31.

13 Spee LAA, Madderom MB, Pijpers M, et al. Association between Helicobacter pylori and gastrointestinal symptoms in children. Pediatrics 2010;125:e651-69.

14 Hernández Vargas C. Rol de la microbiota del jugo gástrico en La respuesta inmune innata de mucosa en La infección pediátrica $P O R$ $H$. pylori [TesisDoctoral]: Pontificia Universidad Católica de Chil, 2019.

15 Kyburz A, Müller A. The gastrointestinal tract microbiota and allergic diseases. Dig Dis 2016;34:230-43.

16 Castaño-Rodríguez N, Kaakoush NO, Lee WS, et al. Dual role of Helicobacter and Campylobacter species in IBD: a systematic review and meta-analysis. Gut 2017;66:235-49.

17 Wang W-L, Xu X-J. Correlation between Helicobacter pylori infection and Crohn's disease: a meta-analysis. Eur Rev Med Pharmacol Sci 2019;23:10509-16.

18 Chen C, Xun P, Tsinovoi C, et al. Accumulated evidence on Helicobacter pylori infection and the risk of asthma: a meta-analysis. Ann Allergy Asthma Immunol 2017;119:e2:137-45.
19 Sabbagh P, Mohammadnia-Afrouzi M, Javanian M, et al. Diagnostic methods for Helicobacter pylori infection: ideals, options, and limitations. Eur J Clin Microbiol Infect Dis 2019;38:55-66.

20 Wang Y-K, Kuo F-C, Liu C-J, et al. Diagnosis of Helicobacter pylori infection: current options and developments. World J Gastroenterol 2015;21:11221-35.

21 Weigt J, Malfertheiner P, Canbay A, et al. Blue light imaging and linked color imaging for the characterization of mucosal changes in chronic gastritis: a clinicians view and brief technical report. Dig Dis 2020;38:9-14.

22 Dimitrov G, Gottrand F. Does gastric atrophy exist in children? World $J$ Gastroenterol 2006;12:6274.

23 O'Ryan ML, Lucero Y, Rabello M, et al. Persistent and transient Helicobacter pylori infections in early childhood. Clin Infect Dis 2015;61:211-8

24 Sugano K, Tack J, Kuipers EJ, et al. Kyoto global consensus report on Helicobacter pylori gastritis. Gut 2015;64:1353-67.

25 Graham DY. Helicobacter pylori update: gastric cancer, reliable therapy, and possible benefits. Gastroenterology 2015;148:719-31.

$26 \mathrm{Kim}$ BJ, Kim HS, Jang HJ, et al. Helicobacter pylori Eradication in Idiopathic Thrombocytopenic Purpura: A Meta-Analysis of Randomized Trials. Gastroenterol Res Pract 2018;2018:6090878

27 Gościniak G, Biernat MM, Bińkowska A, et al. Frequency of infection with Helicobacter pylori isolates of different antimicrobial profiles in children and adolescents: a preliminary study. Adv Clin Exp Med 2017;26:263-8

28 Butenko T, Jeverica S, Orel R, et al. Antibacterial resistance and the success of tailored triple therapy in Helicobacter pylori strains isolated from Slovenian children. Helicobacter 2017;22. doi:10.1111/ hel.12400. [Epub ahead of print: 27 Jun 2017].

29 Shu X, Yin G, Liu M, et al. Antibiotics resistance of Helicobacter pylori in children with upper gastrointestinal symptoms in Hangzhou, China. Helicobacter 2018;23:e12481.

30 Schwarzer A, Bontems P, Urruzuno P, et al. Sequential therapy for Helicobacter pylori infection in treatment-naïve children. Helicobacter 2016;21:106-13.

31 Kori M, Yahav J, Berdinstein R, et al. Primary and secondary antibiotic resistance of Helicobacter pylori in Israeli children and adolescents. Isr Med Assoc J 2017;19:747-50.

32 Iwańczak BM, Borys-Iwanicka A, Biernat M, et al. Assessment of sequential and standard triple therapy in treatment of Helicobacter pylori infection in children dependent on bacteria sensitivity to antibiotics. Adv Clin Exp Med 2016;25:701-8.

33 Georgopoulos SD, Michopoulos S, Rokkas T, et al. Hellenic consensus on Helicobacter pylori infection. Ann Gastroenterol 2020;33:105-24.

34 Moubri M, Kalach N, Larras R, et al. Adapted first-line treatment of Helicobacter pylori infection in Algerian children. Ann Gastroenterol 2019;32:60-6.

35 Kotilea K, Mekhael J, Salame A, et al. Eradication rate of Helicobacter pylori infection is directly influenced by adherence to therapy in children. Helicobacter 2017;22:e12383.

36 Zhou Y, Ye Z, Wang Y, et al. Comparison of four different regimens against Helicobacter pylori as a first-line treatment: a prospective, cross-sectional, comparative, open trial in Chinese children. Helicobacter 2020;25:e12679.

37 Kusano C, Gotoda T, Suzuki S, et al. Safety of first-line triple therapy with a potassium-competitive acid blocker for Helicobacter pylori eradication in children. J Gastroenterol 2018;53:718-24.

38 Ko SW, Kim Y-J, Chung WC, et al. Bismuth supplements as the firstline regimen for Helicobacter pylori eradication therapy: systemic review and meta-analysis. Helicobacter 2019;24:e12565.

39 Fang H-R, Zhang G-Q, Cheng J-Y, et al. Efficacy of Lactobacillussupplemented triple therapy for Helicobacter pylori infection in children: a meta-analysis of randomized controlled trials. Eur $J$ Pediatr 2019;178:7-16.

40 Sarem M, Corti R. Rol de las formas cocoides de Helicobacter pylori en La infección Y La recrudescencia. Gastroenterología y Hepatología 2016;39:28-35. 